\title{
First Publications
}

1. Sirach and the Biblical Canon. Translation of a Spanish original: Ben Sira y el canon de las Escrituras: Greg 78 (1997) 359-370 = in: Nuria Calduch-Benages, Pan de sensatez y agua de sabiduría. Estudios sobre el libro de Ben Sira (ABE. Artículos selectos 1), Estella: Verbo Divino, 2019, 19-31.

2. Sirach and Inspiration. Translation of an Italian original: Il Siracide, un libro deuterocanonico molto particolare, in: Peter DuBovský-Jean-Pierre Sonnet (eds.), Ogni Scrittura è ispirata. Nuove prospettive sull'ispirazione biblica (Lectio 5), Cinisello Balsamo (Milano): GBPress-Edizioni San Paolo, 2013, 124-135.

3. Trial Motif in the Book of Ben Sira, with Special Reference to 2,1-6, in: Pancratius C. Beentjes (ed.), The Book of Ben Sira in Modern Research. Proceedings of the First International Ben Sira Conference 28-31 July 1996 Soesterberg, Netherlands (BZAW 255), Berlin-New York: Walter de Gruyter, 1997, 135-151.

4. Fear of the Powerful or Respect for Authority?, in: Renate EgGER-WEnZEL-Ingrid KRAMmeR (eds.), Der Einzelne und seine Gemeinschaft bei Ben Sira. Festschrift Prof. Friedrich V. Reiterer (BZAW 270), Berlin-New York: Walter de Gruyter, 1998, 87-102.

5. “Cut Her Away from Your Flesh". Divorce in Ben Sira, in: Géza G. Xeravits-József Zsengellér (eds.), Studies in the Book of Ben Sira. Papers of the Third International Conference on the Deuterocanonical Books, Shime‘on Centre, Pápa, Hungary, 18-20 May, 2006 (JSJSup 127), Leiden: Brill, 2008, 81 -95.

6. Animal Imagery in the Hebrew Text of Ben Sirach, in: Jean-Sébastien ReY-Jan Joosten (eds.), The Texts and Versions of the Book of Ben Sira. Transmission and Interpretation (JSJSup 150), Leiden: Brill, 2011, 55-71.

7. The Absence of Named Women from Ben Sira's Praise of the Ancestors, in: Jeremy CorLeYHarm van Grol (eds.), Rewriting Biblical History. Essays on Chronicles and Ben Sira in Honor of Pancratius C. Beentjes (DCLS 7), Berlin: Walter de Gruyter, 2011, $301-317$.

8. Polygamy in Ben Sira?, in: Angelo PASSARo (ed.), Family and Kinship in the Deuterocanonical and Cognate Literature (DCLY 2012/13), Berlin-Boston: Walter de Gruyter, 2013, $127-138$.

9. Good and Bad Wives in the Book of Ben Sira: A Harmless Classification?, in: Christl M. Maier-Nuria Calduch-Benages (eds.), The Writings and Later Wisdom Books (The Bible and Women. Hebrew Bible/Old Testament 1.3), Atlanta, GA: Society of Biblical Literature, 2014, 109-125.

10. Garment Imagery in the Book of Ben Sira, in: Markus WitTE-Sven BehnKE (eds.), The Metaphorical Use of Language in Deuterocanonical and Cognate Literature (DCLY 2014/15), Berlin-Munich-Boston: Walter de Gruyter, 2015, 257-278.

11. The Exodus Traditions in the Book of Ben Sira, in: Judith GÄRTNER-Barbara SCHMITZ (eds.), Exodus. Rezeptionen in deuterokanonischer und frühjüdischer Literatur (DCLS 32), Berlin: Walter de Gruyter, 2016, 117-130.

12. Amid Trials: Ben Sira 2,1 and James 1,2, in: Jeremy CoRLEY-Vincent SKEMP (eds.), Intertextual Studies in Ben Sira and Tobit. Essays in Honor of Alexander A. Di Lella, O.F.M. (CBQMS 38), Washington DC: The Catholic Biblical Association of America, 2005, $255-$ 263. 
13. A Wordplay on the Term mûsar (Sir 6,22), in: Renate EgGER-WENZEL-Karin SCHöPfLINGJohannes Friedrich DIEHL (eds.), Weisheit als Lebensgrundlage. Festschrift für Friedrich V. Reiterer zum 65. Geburtstag (DCLS 15), Berlin-Boston: Walter de Gruyter, 2013, 13-26.

14. Poetic Imagery in the Book of Ben Sira: A Case Study of Sir 21,1-10, in: James K. AITKENRenate Egger-Wenzel-Stefan C. ReIF (eds.), Discovering, Deciphering and Dissenting. Ben Sira Manuscripts after 120 Years (DCLY 2018), Berlin: Walter de Gruyter, 2018, 267-284.

15. Emotions in the Prayer of Sirach 22,27-23,6, in: Stefan C. ReIf-Renate EgGer-WenzeL (eds.), Ancient Jewish Prayers and Emotions. Emotions Associated with Jewish Prayer in and around the Second Temple Period (DCLS 26), Berlin: Walter de Gruyter, 2015, $145-$ 160.

16. Ben Sira 23,27-A Pivotal Verse, in: Nuria Calduch-Benages (ed.), Wisdom for Life. Essays Offered to Honor Prof. Maurice Gilbert, SJ on the Occasion of His Eightieth Birthday (BZAW 445), Berlin: Walter de Gruyter, 2014, 186-200.

17. Ben Sira 24,22-Decoding a Metaphor, in: Andrea TASCHL-ERBER-Irmtraud FISCHER (eds.), Vermittelte Gegenwart. Konzeptionen der Gottespräsenz von der Zeit des Zweiten Tempels bis Anfang des 2. Jahrhunderts n. Chr. (WUNT 367), Tübingen: Mohr Siebeck, 2016, 57-72.

18. Dreams and Folly in Sir 34(31),1-8, in: Irmtraud FISCHER-Ursula RAPP-Johannes SCHILlER (eds.), Auf den Spuren der schriftgelehrten Weisen. Festschrift für Johannes Marböck (BZAW 331), Berlin-New York: Walter de Gruyter, 2003, 241-252.

19. The Hymn to the Creation (Sir 42,15-43,33): A Polemic Text?, in: Angelo PassaroGiuseppe Bella (eds.), The Wisdom of Ben Sira. Studies on Tradition, Redaction, and Theology (DCLS 1), Berlin-New York: Walter de Gruyter, 2008, 119-138.

20. God Creator of All (Sir 43,27-33), in: Renate Egger-Wenzel (ed.), Ben Sira's God. Proceedings of the International Ben Sira Conference, Durham-Ushaw College 2002 (BZAW 321), Berlin-New York: Walter de Gruyter, 2002, 79-100. 